International Journal of Science and Education, 4(1), 43-53

Uluslararası Bilim ve Eğitim Dergisi, 4(1), 43-53

DOI: $10.47477 /$ ubed.886014

Makale Türü: Araştırma Makalesi

Başvuru Tarihi: 01.03.2021

Yayına Kabul Tarihi: 23.04.2021

\title{
Okul Öncesi Dönemde Öz Bakım Becerileri Kazanımlarının Öğretmen Görüşleri Açısından İncelenmesi
}

\author{
Özden Duygu ÇELİK ${ }^{1}$ Çavuş ŞAHİN*2
}

Öz

Bu araştırmanın amacı okul öncesi eğitim programında yer alan öz bakım becerileri alanına ilişkin kazanımların gerçekleşme düzeylerini öğretmen görüşleri doğrultusunda inceleyerek belirlemektir. Araştırma, betimsel yöntem kullanılarak yapılmış bir araştırma olup bu çalışmada tarama modeli kullanılmıştır. Araştırmada 2017-2018 eğitimöğretim yılında Çanakkale il merkezinde bulunan bağımsız anaokullarında çalışan; 51 öğretmene anket formu uygulanmıştır. 51 öğretmen, cevapladıkları her bir öğretmen anketini sınıfında bulunan 10 çocuğu göz önünde bulundurarak toplamda (484) çocuk için cevaplamıştır. Kullanılan anket sonucu alınan veriler bilgisayar ortamında analiz edilmiştir. Yapılan analizlerde öncelikle uygun test tekniği belirlenmiştir. Bunun için her bir bağımsız değişkenin alt gruplardaki cevaplayıcı sayısı ve bağımlı değişkenin bu alt gruplarda normal dağılım gösterme durumu dikkate alınmıştır. Bağımsız değişken alt gruplarının 30'un altında kaldığı durumlarda doğrudan parametrik olmayan testler tercih edilmiş, 30'un üzerinde cevaplayıcı sayısı bulunan bağımsız değişken alt gruplarında ise dağılımların normalliği için Shapiro-Wilk testi sonuçlarına bakılmıştır. Yapılan analizlerde, Shapiro-Wilk testinin bu gruplar için anlamlı sonuç ürettiği $(p>, 05)$ görüldüğünden, bütün analizlerde parametrik olmayan testlerin kullanımı yoluna gidilmiştir. Bağımsız değişkenin iki alt grubunun olduğu durumlarda, "MannWhitney-U”, bağımsız değişkenin üç ve daha fazla alt grubunun olduğu durumlarda ise "Kruskal-Wallis" testleri kullanılmıştır. Anlamlı fark gösteren Kruskal-Wallis testi sonuçlarında ikili karşılaştırmaların yapılabilmesi için Mann-Whitney U testi ile alt grupların farklılıkları tekrar test edilmiştir. Kazanımların gerçekleşmesiyle ilgili öğretmen görüşlerinin betimsel olarak incelemesinde, her bir anketteki alt boyutlar için toplam cevaplayıcı sayısı $(\mathrm{N})$, aritmetik ortalama $(X)$ ve standart sapma (S.s.) değerleri kullanılmıştır. Araştırmada katılımcı öğretmen görüşlerine göre eğitim programında yer alan öz bakım becerileri alanlarıyla ilgili kazanımların "yüksek düzeyde" gerçekleştirildiği sonucuna ulaşılırken, en az gerçekleştiği düşünülen öz bakım becerileri kazanımları "sağlığı ile ilgili önlemleri alır" şeklinde karşımıza çıkmaktadır

Anahtar Kelimeler: Kazanımlar, okul öncesi eğitim programı, öz bakım becerileri.

\footnotetext{
* Bu çalışma 1. yazarın "Okul Öncesi Eğitim Programındaki Dil Gelişimi ve Öz Bakım Becerilerine İlişkin Kazanımların Gerçekleşme Düzeylerinin İncelenmesi' adlı yüksek lisans tezinden üretilmiştir.

1 Öğr. Gör., Dicle Üniversitesi Meslek Yüksek Okulu, ozdenduygucelik@gmail.com, ORCID: 0000-0002-8471-3723

${ }^{2 *}$ Corresponding Author: Prof. Dr, Çanakkale Onsekiz Mart Üniversitesi Eğitim Fakültesi, Turkey, csahin25240@yahoo.com, ORCID: 0000-0002-7175-4702
} 


\title{
Examining Self-Care Skills Acquisitions in Preschool Period in Terms Of Teachers Opinions
}

\begin{abstract}
The general purpose of this study is to determine the level of realization of the acquisitions in the field of self-care skills in the preschool education program by examining the teachers' opinions. The research was conducted using descriptive method, and survey model was used in this study. In the research, working in independent kindergartens in Çanakkale city center in 2017-2018 academic year; A questionnaire form was applied to 51 teachers. 51 teachers answered each teacher questionnaire for a total of (484) children, considering 10 children in their class. The data obtained as a result of the questionnaire used were analyzed in computer environment. In the analysis, firstly, the appropriate test technique was determined. For this, the number of respondents in the subgroups of each independent variable and the normal distribution of the dependent variable in these subgroups were taken into account. In cases where the independent variable subgroups were below 30, non-parametric tests were preferred, and the Shapiro-Wilk test results were examined for the normality of distributions in the independent variable subgroups with more than 30 respondents. As it was seen in the analyzes that the ShapiroWilk test produced significant results for these groups ( $p>.05)$, nonparametric tests were used in all analyzes. In cases where the independent variable has two subgroups, "Mann-Whitney-U" tests were used, and in cases where the independent variable has three or more subgroups, "Kruskal-Wallis" tests were used. In order to make paired comparisons in the Kruskal-Wallis test results, which showed a significant difference, the differences of the subgroups were retested with the Mann-Whitney U test. In the descriptive analysis of teachers' views on the realization of the outcomes, the total number of respondents $(\mathrm{N})$, arithmetic mean $(\mathrm{X})$ and standard deviation $(\mathrm{S} . \mathrm{s}$.) values were used for the sub-dimensions in each questionnaire. According to the opinions of the participant teachers in the study, it is concluded that the acquisitions related to the self-care skills fields in the education program are achieved at a "high level", while the self-care skills acquisitions that are thought to be the least occur as "taking measures related to health".
\end{abstract}

Key Words: Acquisitions, preschool education program, self-care skills.

\section{Giriş}

Okul öncesi eğitim, çevresine karşı merak duygusu besleyen, keşfetmeye hazır, öğrenmek ve düşünmek için güdülenmiş çocukların var olan potansiyellerinde taşıdıkları bu özellikleri geliştirme, yönetme, teşvikle destekleme gibi çok önemli bir görevi üstlenmektedir. Çocuklarda gelişimi sağlayabilmek, sistemli olarak karmaşık becerileri kazanmaları noktasında yol göstermek, gelişim alanlarını destekleyerek bireysel farklılıkları doğrultusunda kendi potansiyellerini bulmalarına yardımcı olabilmek adına uzman kişiler tarafından hazırlanmış eğitim programlarına ihtiyaç duyulmaktadır. Okul öncesi programı, eğitim alan çocukların çeşitli öğrenim deneyimleriyle birlikte sağlıklı büyümelerini, sosyal-duygusal, psiko-motor, bilişsel ve dilsel alanlara ait gelişimlerinin üst seviyelere çıkarılmasını, öz bakım becerilerini yerine getirebilir hale getirilmelerini ve ilköğretim kademesine hazır hale gelmelerini hedeflemektedir (Milli Eğitim Bakanlığı [MEB], 2013).

Okul öncesi eğitim, çocukların doğdukları gün ile ilköğretime başladıkları güne kadar geçen süre zarfındaki tüm yaşantılarını kapsayan bir eğitim sürecidir. Bu dönemde beyin gelişimi ve sinaptik bağlantıların oluşumu çok yoğun ve hızlı bir şekilde ilerlemektedir. Bu gelişimle birlikte psiko-motor, dilsel, bilişsel, sosyal ve duygusal beceriler adına sağlam temel atımları sağlanmaktadır (Atay, 2005). Çocukların gelişimlerini desteklemeyi planladığımız, onlara kazandırmayı hedeflediğimiz bilgi ve beceriler, var olan eğitim sistemimiz aracılığıyla gerçekleştirilip aile, çevre ve diğer faktörler yoluyla desteklenmektedir. Eğitim sistemi içerisinde yer alan eğitim programları ışığında eğitim-öğretim süreçlerinin öncesinde planlanıp daha sonra uygulamaya konulup en son aşama olarak ise değerlendirilmesi gerekmektedir.

Günümüzde 2013 yılından itibaren uygulamaya konan ve hala uygulanmakta olan "Okul Öncesi Eğitim Programı" 3-6 yaş grubundaki çocukların zenginleştirilmiş çevresel koşullar içerisinde 
gelişmelerini, sahip oldukları gelişim alanlarının desteklenerek bu alanlarda ulaşabilecekleri en iyi noktaya gelmelerini, temel öz bakım becerilerinin kazandırılmasıyla birlikte bir sonraki eğitim kademesine hazır durumda bulunmaların hedeflemektedir (MEB, 2013).

Okul öncesi dönemde öğretmenlerin eğitim-öğretim süreçlerinde sahip oldukları yeterlilik düzeyi, var olan programın etkili bir şekilde uygulanması ve öğrencilerin sonraki eğitim kademelerine sağlam temellerle ilerleyebilmeleri açısından son derece önemlidir. Bu alanda yapılan çalışmaları incelediğimizde Köksal, Doğal ve Duman (2016)'nın okul öncesi öğretmenleri ile yapmış oldukları çalışma karşımıza çıkmaktadır. Bu çalışmada öğretmenlerin eğitim programıyla ilgili sahip oldukları görüşler belirlenmeye çalışılmıştır. Araştırmadan çıkan sonuca baktığımızda öğretmenlerinin görüşlerinin program kazanımları ve göstergeleri noktasında olumlu yönde olduğu görülmüştür. Öğreticilerin kazanımları ve göstergeleri belirlerken öğrenci ihtiyaçlarını dikkat aldıkları yine araştırma sonucu olarak karşımıza çıkmaktadır. Ulaşılan sonuçlar doğrultusunda programın öğretmenlerden alınan dönütler ışığında değerlendirilip, programa bu doğrultuda eklenmesi muhtemel yeni kazanımların ve göstergelerin tespit edilip, aile katılımına dair programların yeniden değerlendirilerek revize edilmesi gerektiği görülmüştür. Araştırma sonuçlarına bağlı olarak okul öncesi eğitimde program kalitesinin arttırılması için ileri dönemlerde bu alanda yapılacak olan araştırmaların varlığı önemlidir.

$\mathrm{Bu}$ araştırma okul öncesi eğitim programında yer alan öz bakım becerileri ile ilgili kazanımların gerçekleşme düzeylerini incelemek amacıyla gerçekleştirilmiştir. Programda yer alan kazanımların öğretmenlere uygulanan anketler sonucunda demografik bilgilerinde göz önünde bulundurularak incelenmesi ve kazanımların gerçekleşme düzeylerinin tespit edilmesi amaçlanmıştır. Mevcut programda bulunan öz bakım becerileri kazanımlarının öğretmen görüşleri açısından incelenerek gerçekleşme düzeylerinin belirlenmesi, ileri dönemlerde programın etkililiğinin arttırılması için bu alanda yapılacak çalışmalara yardımcı olmayı hedeflemektedir. Bu doğrultuda araştırma soruları aşağıdaki gibi belirlenmiştir:

1) Okul öncesi eğitim programında bulunan öz bakım becerileri alanına ilişkin kazanımların gerçekleşmesiyle ilgili öğretmen görüşleri nelerdir?

2) Okul öncesi eğitim programında bulunan öz bakım becerileri alanına ilişkin kazanımlar öğretmen görüşlerine göre hangi düzeyde gerçekleşmektedir?

3) Okul öncesi eğitim programında bulunan öz bakım becerileri alanına yönelik kazanımların gerçekleşme düzeyleriyle ilgili öğretmen görüşleri:

a) Okul türü,

b) Çalışılan yaş grubu,

c) Çalışılan sınıf mevcudu ve

d) Hizmet yılı değişkenlerine göre anlamlı biçimde farklılaşmakta mıdır?

\section{Yöntem}

\section{Araştırma Modeli}

Tarama modeli araştırmalar sosyal bilimlerde sıklıkla kullanılan ve araştırmaya konu olan özellikleri belirlemek amacıyla yapılan betimsel araştırmalardır (Can, 2019). Tarama modeli araştırmalarda geçmiş dönemde var olmuş ya da hala var olmaya devam eden durumların, oldukları biçimde betimlenmesi amaçlanıp ortada var olan durumlar, kişiler yahut nesneler kendi koşullarına bağlı kalınarak var oldukları şekilde aktarılmaya çalışılır. Tarama modelinde durumun herhangi bir değişikliğe uğratılma çabası söz konusu değildir (Karasar, 2002). Bu araştırmada okul öncesi eğitim programında yer alan öz bakım becerileri alanına ilişkin kazanımların, öğretmen görüşleri doğrultusunda gerçekleşme düzeyleri belirlenmeye çalışılmıştır. Program kazanımlarına dair öğretmen görüşlerinin bir değişikliğe uğramadan olduğu gibi araştırma sonuçlarına yansıması 
hedeflenmektedir. Bu sebeple bu araştırma tarama modelinde yapılmış olup çalışma olarak betimsel bir çalışma olma özelliği taşımaktadır.

\section{Evren ve Örneklem}

Araştırmanın evrenini 2017-2018 eğitim öğretim yılında Çanakkale il merkezinde bulunan bağımsız anaokulları oluşturmaktadır. Araştırmanın örneklemini Çanakkale ili merkezinde bulunan bağımsız anaokullarında görev yapan; 51 öğretmen oluşturmaktadır. 51 öğretmen, cevapladıkları her bir öğretmen anketini sınıfında bulunan yaklaşık 10 çocuğu göz önünde bulundurarak toplamda (484) çocuk için cevaplamıştır.

"Öğretmen Anketi" için cevaplayıcıların dağılımları değişkenlere göre tablolaştırılıp belirtilmiştir.

Tablo 1. Öğretmen Anketi İçin Cevaplayıcıların “Okul Adı, Hizmet Yılı ve Çalışılan Sınıf Mevcudu" Değişkenlerine Göre Dağılımı

\begin{tabular}{llll}
\hline & Grup & (f) & $\%$ \\
\hline \multirow{4}{*}{ Okul adı } & Atatürk A.O. & 10 & 19,6 \\
& Aliağa A.O. & 13 & 25,5 \\
& H.A.T. A.O. & 12 & 23,5 \\
& Zübeyde H. A.O. & 16 & 31,4 \\
& $0-5$ yıl & 8 & 15,7 \\
Hizmet yılı & $6-10$ yıl & 12 & 23,5 \\
& $11-15$ yıl & 22 & 43,1 \\
& $16-25$ yıl & 3 & 5,9 \\
& 25 üzeri yıl & 6 & 11,8 \\
Çalışılan sınıf mevcudu & $10-15$ & 8 & 15,7 \\
& $16-20$ & 18 & 35,3 \\
& $21-25$ & 19 & 37,3 \\
& $25+$ & 6 & 11,8 \\
\hline & N:51* & &
\end{tabular}

Tablo 2. Öğretmen Anketi İçin Cevaplayıcıların “Çalışılan Yaş Grubu, Cinsiyet ve Hizmet İçi Eğitim” Değişkenlerine Göre Dağılımı

\begin{tabular}{llll}
\hline & Grup & (f) & $\%$ \\
\hline \multirow{3}{*}{ Çalışılan yaş grubu } & $36-48$ ay & 7 & 13,7 \\
& $48-60$ ay & 26 & 51,0 \\
\multirow{3}{*}{ Cinsiyet } & 60 ay üzeri & 18 & 35,3 \\
& Erkek & 1 & 2,0 \\
\multirow{2}{*}{ Hizmet içi eğitim } & Kadın & 50 & 98,0 \\
& Evet & 50 & 98,0 \\
& Hayır & 1 & 2,0 \\
\hline & ${ }^{*} \mathrm{~N}=51$ & &
\end{tabular}

\section{Veri Toplama Araçları}

$\mathrm{Bu}$ araştırmada okul öncesi eğitim programında yer alan öz bakım becerilerine ilişkin kazanımların gerçekleşme düzeylerinin incelenmesini hedeflemektedir. Veri toplama aracı olarak, öz bakım becerileri kazanımlarını içeren MEB'in 2013 okul öncesi eğitim programında yer alan öz bakım becerilerine ait kazanımların düzenlendiği ve içerisinde, öğretmenlere ait kişisel bilgilerin yer aldığ1 "Öğretmen Anketi" kullanılmıştır. Öğretmen Anketi, MEB tarafından hazırlanmış ve içerisinde bulunduğumuz dönemde uygulanmakta olan okul öncesi eğitim programı kazanımları ve bu çalışma 
alanı ile ilgili olarak yapılmış bağlantılı araştırmalara ait anketlerin incelenmesi sonucu oluşturulmuştur.

Okul öncesi öğretmenlerine anket hazırlanmıştır. Anket iki bölümden oluşmaktadır. Anketin birinci bölümünde öğretmenlere ait kişisel bilgiler yer almaktadır. İkinci bölümündeyse programda yer alan öz bakım becerilerine yönelik kazanımların gerçekleşme düzeylerine yönelik maddeler yer almaktadır. Oluşturulan maddeler çalışma gruplarına uygulanmadan önce bir pilot uygulama yapılmıştır. Uygulama sonucunda ulaşılan veriler bilgisayar yazılımına aktarılarak güvenirlik çalışması yapılmıştır. Bu pilot uygulama sonucu oluşturulan öğretmen anketi güvenirlik katsayıları yüksek derecede güvenilir bulunmuştur. Anketten soru çıkarılmasına ya da eklenmesine ihtiyaç duyulmamıştır. Anket içerisinde yer alan kazanımların gerçekleşme düzeylerini belirleyebilmek amacıyla "Tamamen Katılıyorum, Katılıyorum, Az Katılıyorum, Katılmıyorum, Hiç Katılmıyorum" seçenekleri kullanılmıştır. Katılma düzeylerine baktığımızda; tamamen katılıyorum "çok yüksek", katılıyorum "yüksek", az katılıyorum "orta", katılmıyorum "düşük" ve hiç katılmıyorum "çok düşük" olarak değerlendirilmiştir. "Öğretmen Anketinin" kazanımlarına göre madde sayıları ve güvenirlik analizi sonuçları Tablo 3'te gösterilmiştir.

Tablo 3. Öğretmen Anketi Kazanımlarının Madde Sayıları ve Güvenirlik Analizi Sonuçları

\begin{tabular}{lll}
\hline & $\begin{array}{l}\text { Madde } \\
\text { Sayıları }\end{array}$ & $\begin{array}{l}\text { Öğretmen Anketi } \\
(\boldsymbol{\alpha})\end{array}$ \\
\hline $\begin{array}{l}\text { Öz Bakım Becerileri Alanına } \\
\text { İlişkin Kazanımlar }\end{array}$ & 8 & .953 \\
\hline
\end{tabular}

\section{Verilerin Analizi}

Araştırmada toplanan verilerin analiz sürecinde çeşitli yazılımlardan yararlanılmıştır. Anket uygulaması sonucu toplanan veriler IBM SPSS 21.00 paket veri programı ile analiz edilmiştir. Elde edilen verilerin analizinde ve yorumlanmasında aşağıdaki ilkeler göz önünde tutulmuştur:

1) Programda bulunan öz bakım becerileri alanlarına ilişkin kazanımların gerçekleşmesiyle ilgili öğretmen ve veli görüşlerinin betimsel incelemesinde her bir anketteki alt boyutlar için toplam cevaplayıcı sayısı $(\mathrm{N})$, aritmetik ortalama $(\bar{X})$ ve standart sapma (s.s.) değerleri kullanılmıştır.

2) Programda bulunan öz bakım becerileri alanlarına ilişkin kazanımların öğretmen görüşlerine göre gerçekleşme düzeyleri boyut bazında incelenirken, boyutların aritmetik ortalamaları $(X)$ dikkate alınmış ve minimum ve maksimum ortalama değer aralığı $(1,00$ $5,00)$ beş eşit alt aralığa bölünerek katılım her bir boyuttaki kazanımların gerçekleşme düzeyleri bulunmuştur. Tablo 4 boyutlar için ortalama puan aralıklara ve bu aralıklara karşılık gelen katılım düzeyini göstermektedir.

Tablo 4. Boyut Ortalamalarının Yorumlanmasında Kullanılan Puan Aralıkları ve Kazanımların Gerçekleşme Düzeyleri

\begin{tabular}{ll}
\hline Ortalama puan & Katılım düzeyi \\
\hline $1,00-1.79$ & Çok Düşük \\
$1,80-2,59$ & Düşük \\
$2,60-3,39$ & Orta \\
$3,40-4,19$ & Yüksek \\
$4,20-5,00$ & Çok Yüksek \\
\hline
\end{tabular}

3) Öğretmen katılımcılarının cevaplarının analize uygun hale getirilebilmesi için, her bir öğretmenin farklı öğrenciler için doldurduğu anketlerin madde bazında aritmetik ortalamaları hesaplanarak öğretmen bazında madde puanları elde edilmiştir. 
4) Programda bulunan öz bakım becerileri alanlarına yönelik kazanımların gerçekleşme düzeyleriyle ilgili öğretmen görüşlerinin çeşitli bağımsız değişken gruplarına göre anlamlı farklılıkları incelenirken öncelikle uygun test tekniği belirlenmiştir. Bunun için her bir bağımsız değişkenin alt gruplardaki cevaplayıcı sayısı ve bağımlı değişkenin bu alt gruplarda normal dağılım gösterme durumu dikkate alınmıştır. Bağımsız değişken alt gruplarının 30'un altında kaldığı durumlarda doğrudan parametrik olmayan testler tercih edilmiş, 30'un üzerinde cevaplayıcı sayısı bulunan bağımsız değişken alt gruplarında ise dağılımların normalliği için Shapiro-Wilk testi sonuçlarına bakılmıştır. Yapılan analizlerde, Shapiro-Wilk testinin bu gruplar için anlamlı sonuç ürettiği $(p>, 05)$ görüldüğünden, bütün analizlerde parametrik olmayan testlerin kullanımı yoluna gidilmiştir. Sonuç olarak, bağımsız değişkenin iki alt grubunun olduğu durumlarda, "Mann-Whitney-U”, bağımsız değişkenin üç ve daha fazla alt grubunun olduğu durumlarda ise "Kruskal-Wallis" testleri kullanılmışır. Anlamlı fark gösteren Kruskal-Wallis testi sonuçlarında ikili karşılaştırmaların yapılabilmesi için Mann-Whitney U testi ile alt grupların farklılıkları tekrar test edilmiştir. (Büyüköztürk, 2010).

5) Anlamlılık düzeyi iki yönlü olarak test edilmiş ve anlamlı farklılık $(p<, 05)$ düzeyinde incelenmiştir.

\section{Bulgular}

Bu kısımda, nicel veri toplama araçları yoluyla elde edilen verilerin analiz edilmesi sonucunda ortaya konan bulgular sunulmuştur. Bu kapsamda önce okul öncesi eğitim programında yer alan öz bakım becerileri alanlarına ilişkin kazanımların gerçekleşmesiyle ilgili öğretmen görüşleri ortaya konulmuştur. Daha sonra, bu alanlara ait kazanımları gerçekleşme düzeyleri incelenmiş ve bu alanlarda öğretmen görüşlerindeki anlamlı farklılıkların bağımsız değişkenlere göre incelenmesi sonucunda anlamlı farklılaşma durumları analiz edilip elde edilen bulgular açıklanmıştır.

\section{Programda Yer Alan Öz Bakım Becerileri Alanına İlişkin Kazanımların Gerçekleşmesiyle İlgili Öğretmen Görüşleri}

Çalışmanın birinci araştırma sorusu olan "Programda yer alan öz bakım becerileri alanına ilişkin kazanımların gerçekleşmesiyle ilgili öğretmen görüşleri nelerdir?" sorusuna yönelik bulgular öğretmen anketindeki her alt boyut için ayrı ayrı incelenmiştir. Tablolar öğretmen anketinden elde edilen bulguları göstermektedir.

Tablo 5. Programda Yer Alan Öz Bakım Becerileri Alanlarına İlişkin Kazanımların Gerçekleşmesiyle İlgili Öğretmen Görüşleri

Madde/Cevap

Öz bakım becerileri

1. Bedeniyle ilgili temizlik kurallarını uygular.

$\bar{X} \quad$ Ss.

2. Giyinme ile ilgili işleri yapar.

$4,28 \quad 63$

3. Yaşam alanlarında gerekli düzenlemeler yapar.

$4,18 \quad, 54$

4. Yeterli ve dengeli beslenir.

$4,22 \quad, 53$

5. Dinlenmenin önemini açıklar.

$4,11 \quad 60$

6. Günlük yaşam becerileri için gerekli araç ve gereçlerini kullanır.

$4,17 \quad, 57$

7. Kendini tehlikelerden ve kazalardan korur.

$4,26 \quad, 55$

8. Sağlığı ile ilgili önlemler alır.

$4,09 \quad 66$

$4,04 \quad 63$

${ }^{*} \mathrm{~N}=51$

Tablo 5 'te öz bakım becerileri alanında, bedeniyle ilgili temizlik kurallarını uygulama $(X=4,28)$ ve günlük yaşam becerileri için gerekli araç ve gereçleri kullanma $(X=4,26)$ en çok gerçekleşen 
kazanımlar olarak görülürken, sağllğ 1 ile ilgili önlemler alma $(X=4,04)$ ve kendini tehlikelerden ve kazalardan koruma $(X=4,09)$ en az kazanımın gerçekleştiği beceriler olarak ifade edilmiştir.

\section{Öğretmen Görüşlerine Göre Programda Yer Alan Öz Bakım Becerileri Alanına İlişkin Kazanımların Gerçekleşme Düzeyleri}

Çalışmanın ikinci araştırma sorusu olan programında yer alan öz bakım becerileri alanlarına ait kazanımların öğretmen görüşlerine göre gerçekleşme düzeyi, katılımcı grubu ve anket boyutu için incelenmiş̧ir. Tablo 5 öğretmen görüsslerine göre eğitim programında yer öz bakım becerilerine ait kazanımların gerçekleşme düzeylerini göstermektedir.

Tablo 6. Öğretmen Görüşlerine Göre Programda Yer Alan Öz Bakım Becerilerine Ait Kazanımların Gerçekleşme Düzeyi

\begin{tabular}{lllll}
\hline Katılımcı grubu & Boyut & $\mathbf{N}$ & $\overline{\mathbf{X}}$ & Gerçekleşme düzeyi \\
\hline Öğretmen & Öz bakım becerileri & 51 & 4,17 & Yüksek \\
\hline
\end{tabular}

Tablo 6'dan anlaşılabileceği üzere, katılımcı öğretmen görüşlerine göre, eğitim programında yer alan öz bakım becerilerine $(X=4,17)$ ilişkin kazanımlar yüksek düzeyde gerçekleşmektedir.

\section{Programda Yer Alan Öz Bakım Becerileri Alanına İlişkin Öğretmen Görüşlerindeki Anlamlı Farklılıkların Bağımsız Değişkenlere Göre İncelenmesi}

Çalışmanın üçüncü araştırma sorusu, eğitim programında yer alan öz bakım becerileri alanlarına ilişkin öğretmen görüşlerinin çeşitli bağımsız değişkenlerin alt gruplarına göre anlamlı biçimde farklılaşma durumunu incelemektedir. Bu araştırma sorusu ile ilgili bulgular, normal dağglım varsayımı, bağımsız değişkenlerin alt grupları ve bu gruplardaki katılımcı sayıları dikkate alınarak Kruskal-Wallis testi sonuçlarına göre elde edilmiş ve her bir anket boyutu için ilgili değişkenlere göre gruplanarak tablolaştırılmıştır. Tablo 7, 8, 9 ve 10 eğitim programında yer alan öz bakım becerileri alanlarına ilişkin kazanımların gerçekleşme düzeyiyle ilgili öğretmen görüşlerinde okul adı, çalışılan sınıf mevcudu ve çalışılan yaş gurubuna göre anlamlı farklılaşmaları göstermektedir.

Tablo 7. Öz Bakım Becerilerine İlişkin Kazanımların Gerçekleşme Düzeyiyle İlgili “Okul” Değişkenine Göre Öğretmen Görüşlerindeki Anlamlı Farklılıklar (Kruskal-Wallis Testi Sonuçları)

\begin{tabular}{llllllll}
\hline Boyutlar & Değişken/Okul & N & Sıra Ort. & Sd & $\chi^{2}$ & p & Fark \\
\hline \multirow{3}{*}{ Özbakım becerileri } & (1) Atatürk A.O. & 10 & 30.80 & & & & \\
& (2) Ali Ağaoğlu & 13 & 25.77 & & & & \\
& (3) H.A.T A.O. & 12 & 24.75 & 3 & 1.386 & .709 & \\
& (4) Zübeyde Hanım & 16 & 24.13 & & & & \\
\hline \multicolumn{7}{c}{${ }^{*} p<, 05$}
\end{tabular}

Tablo 7'de çalışmaya katılan öğretmenlerin görev yaptıkları okula göre öz bakım becerileri [ $\chi 2=1.386, p>.05]$ boyutunda görüşlerinin anlamlı bir şekilde farklılaşmadığ görülmektedir.

Tablo 8. Öz Bakım Becerilerine İlişkin Kazanımların Gerçekleşme Düzeyiyle İlgili "Sınıf Mevcudu" Değişkenine Göre Öğretmen Görüşlerindeki Anlamlı Farklılıklar (Kruskal-Wallis Testi Sonuçları)

\begin{tabular}{llllllll}
\hline Boyutlar & Değişken/ Sınıf Mevcudu & N & Sıra Ort. & Sd & $\chi^{2}$ & P & Fark \\
\hline \multirow{3}{*}{ Özbakım becerileri } & (1) $10-15$ yıl & 8 & 22.88 & & & & \\
& (2) $16-20$ yıl & 18 & 21.81 & 2 & .304 & .859 & \\
& (3) $21-25$ yıl & 19 & 24.18 & & & & \\
\hline
\end{tabular}


Benzer şekilde Tablo 8 'de öğretmenlerin çalıştıkları sınıfların mevcuduna göre öz bakım becerileri $[\chi 2=.304, p>.05]$ boyutunda görüşlerinin anlamlı bir şekilde farklılaşmadığı görülmektedir.

Tablo 9. Öz Bakım Becerilerine İlişkin Kazanımların Gerçekleşme Düzeyiyle İlgili “Çalışılan Yaş Grubu" Değişkenine Göre Öğretmen Görüşlerindeki Anlamlı Farklılıklar (Kruskal-Wallis Testi Sonuçları)

\begin{tabular}{|c|c|c|c|c|c|c|c|c|}
\hline Boyutlar & $\begin{array}{l}\text { Değişken/ Çalışılan } \\
\text { Grubu }\end{array}$ & Yaş & $\mathbf{N}$ & Sira Ort. & sd & $\chi^{2}$ & $\mathbf{P}$ & Fark \\
\hline \multirow{3}{*}{ Özbakım becerileri } & (1) $36-48$ ay & & 7 & 15.7 & & & & \\
\hline & (2) $48-60$ ay & & 26 & 27.56 & 2 & 4.397 & .111 & \\
\hline & (3) 60 ay üzeri & & 18 & 28.0 & & & & \\
\hline
\end{tabular}

${ }^{*} \mathrm{p}<, 05$

Tablo 9'u incelediğimizde, çalışmaya katılan öğretmenlerin çalıştıkları öğrenci yaş gruplarına göre öz bakım becerileri [ $\chi 2=.4 .397, \mathrm{p}>.05]$ boyutunda görüşlerinin anlamlı bir şekilde farklılaşmadığ 1 görülmektedir.

Tablo 10. Öz Bakım Becerilerine İlişkin Kazanımların Gerçekleşme Düzeyiyle İlgili "Hizmet Yılı" Değişkenine Göre Öğretmen Görüşlerindeki Anlamlı Farklılıklar (Kruskal-Wallis Testi Sonuçları)

\begin{tabular}{|c|c|c|c|c|c|c|c|c|}
\hline \multirow[t]{2}{*}{ Boyutlar } & \multicolumn{2}{|c|}{ Değişken/ Hizmet Yılı } & \multirow{2}{*}{$\frac{N}{8}$} & \multirow{2}{*}{$\frac{\text { Sira Ort. }}{18.06}$} & \multirow[t]{2}{*}{ Sd } & \multirow[t]{2}{*}{$\chi^{2}$} & \multirow[t]{2}{*}{ p } & \multirow[t]{2}{*}{ Fark } \\
\hline & (1) & $0-5$ yıl & & & & & & \\
\hline \multirow{4}{*}{ Özbakım becerileri } & (2) & 6-10 y1l & 12 & 26.67 & & & & \\
\hline & (3) & $11-15$ yil & 22 & 27.41 & 4 & 2.855 & .582 & \\
\hline & (4) & $16-25$ y1l & 3 & 27.17 & & & & \\
\hline & $(5)$ & 25 ve üzeri yıl & 6 & 29.50 & & & & \\
\hline
\end{tabular}

Ayrıca, çalışmaya katılan öğretmenlerin kıdemlerine (hizmet yılına) göre de öz bakım becerileri $[\chi 2=.582, p>.05]$ boyutundaki görüşlerinde anlamlı bir şekilde farklılaşma bulunmamıştır.

\section{Tartışma, Sonuç ve Öneriler}

Araştırmada okul öncesi eğitim programında yer alan öz bakım becerileri alanına ilişkin kazanımların gerçekleşmesiyle ilgili öğretmen görüşlerine baktığımızda, katılımcı öğretmenlerin, öz bakım becerileri alanlarına ilişkin kazanımlardan en çok "bedeniyle ilgili temizlik kurallarını uygular ve günlük yaşam becerileri için gerekli araç ve gereçleri kullanır" kazanımlarının gerçekleştiğini düşündükleri sonucuna ulaşılmıştır. Katılımcı öğretmenlerin, öz bakım becerileri alanında en az gerçekleştirildiği düşündükleri kazanımların "kendini tehlikelerden ve kazalardan korur ve sağlığı ile ilgili önlemleri alır" olduğu sonucuna ulaşılmıştır. Katılımcı öğretmen görüşlerine göre eğitim programında yer alan öz bakım becerileri alanıyla ilgili kazanımların "yüksek düzeyde" gerçekleştirildiği sonucuna ulaşılmıştır. Özsırkıntı, Akay ve Bolat (2014)'ın yaptıkları çalışmada, 2013 eğitim döneminde pilot illerde bulunan pilot okullarda uygulamaya konulan programın, pilot kurumlarda çalışmakta olan öğretmen görüşleri açısından değerlendirilmesi amaçlanmıştır. Çalışma sonucuna baktığımızda eğitmenlerin genelinde program hakkında pozitif düşüncelerin yer aldığı söylenebilir. Aynı zamanda yapılan herhangi bir değişiklik noktasında kazanım ve göstergeler açısından öğretmenlerin pozitif tutum sergilediği sonucuna ulaşılmıştır. Araştırmanın sonuçları bu çalışma sonuçlarını destekler niteliktedir.

Öz bakım becerileri alanına ilişkin kazanımların gerçekleşme düzeyiyle ilgili öğretmen görüşlerindeki anlamlı farklılıklara bakıldığında, çalışmaya katılan öğretmenlerin "görev yaptıkları 
okula, çalıştıkları sınıf mevcuduna ve çalıştıkları hizmet yılına (kıdemlerine)" göre anlamlı bir farklılaşma olmadığı sonucuna ulaşılmıştır.

Çalışmada ilk araştırma sorusu olan "programda yer alan öz bakım becerileri alanlarına ilişkin kazanımların gerçekleşmesiyle ilgili öğretmen görüşleri nelerdir?" sorusu incelendiğinde, öğretmenler genel olarak olumlu görüş bildirmişlerdir. Katılımcı öğretmen görüşlerine göre eğitim programında yer alan öz bakım becerileri alanıyla ilgili kazanımların "yüksek düzeyde" gerçekleştirildiği sonucu görülmüştür. Kazanımların gerçekleştirilmesi ve kazanım edinme ile ilgili çalışmaları incelediğimiz noktada; Uzun (2007) yaptığı araştırmada, öğretmenlerin büyük bir kısmının etkinlikleri hazırlarken hedefler doğrultusunda etkinlikleri planlayarak öğrencilerin ilgi ve ihtiyaçlarının göz önünde bulundurulduğu sonucuna ulaşmıştır. Başka bir araştırmada ise Kay (2015) yaptığı çalışmada; kazanım ve göstergelerin gerçekleştirilmesini zorlaştıran durumları her bölgeyle uyumlu olamaması, imkân eksikliği ve özel gereksinimli bireylere uygun kazanım ve göstergelerin olmayışıyla küçük yaş grubundaki çocukların zorlanıyor olması şeklinde ayrıldığını belirtmiştir.

Araştırmada öz bakım becerileri alanına ilişkin kazanımların gerçekleşme düzeyiyle ilgili öğretmen görüşlerine göre, çalışmaya katılan öğretmenlerin "görev yaptıkları okula, çalıştıkları sınıf mevcuduna ve çalıştıkları hizmet yılına (kıdemlerine)" göre anlamlı bir farklılaşma olmadığı görülmüştür. Konuyla ilgili yapılan araştırmalar incelendiğinde; İş (2017) tarafından yapılan çalışmada okul öncesi öğretmenleri ve sınıf öğretmenleri tarafından, 2013 programında yer alan kazanımların çocuklardaki gerçekleşme durumlarına yönelik sahip oldukları algılar incelenmiştir. Çalışmada nicel ve nitel yöntem birlikte kullanılmıştır. Araştırmanın sonucunda nicel verilerle ilgili olarak, okul öncesi öğretmenleri kazanımları edindirmeye, programın uygulanabilirliğiyle ilgili anketteki ifadelere pozitif yönde görüş bildirdikleri görülmüştür. Nitel sonuçlara bakıldığında ise; okul öncesi öğretmenlerinin programdaki kazanımları edindirmeye yönelik görüşleri değişmezken, sını öğretmenlerinin, bazı alanlardaki yetersizliklere de dikkat çekerek genel itibarı ile programın etkililiği yönünde olumlu görüş bildirdikleri tespit edilmiştir. Araştırma bulguları mevcut araştırma sonuçlarını da destekler niteliktedir.

Okul öncesi eğitim programında yer alan kazanımların gerçekleşme düzeyleri programın etkililiği ve yeterliliği konusunda bizlere bilgi vermektedir. Bu konuda yapılan araştırmaları incelediğimizde; Özkesmen (2008) yaptığı çalışmada okul öncesine kurumlarında eğitim almış ve bu eğitimden faydalanmamış, birinci sınıf çocuklarının, uygulanan yeni programa göre akademik açıdan değerlendirilmelerini incelemiştir. Araştırmada okul öncesi eğitimi alan öğrencilerin sosyal, bilişsel, dilsel ve psiko-motor alanlarda, almayan öğrencilere nazaran daha iyi oldukları sonucuna ulaşmıştır. Bununla beraber öz bakım becerilerle ilgili ise her iki grup arasında anlamlı bir farklılaşma görülmediğini ifade etmiştir.

Alan açısından benzeyen bir araştırmada Ekinci (2011) çocukların okul öncesi kurumlarına gitmelerinin ve bu eğitimden yararlanmalarının ilköğretime başladıkları zamanki etkisini araştırmıştır. Çalışmada okul öncesi eğitimi almış olan çocukların; bilişsel, duygusal-sosyal gelişim türlerinde okul öncesi eğitimi almamış çocuklardan daha iyi bir durumda oldukları sonucunu tespit etmiştir.

Unutkan (2007) tarafından yapılan bir araştırmaya göre, okul öncesi eğitim almış çocukların okul öncesi eğitim almamış çocuklara nazaran dikkat ve hafıza gerektiren, sıralama yapmayı, artırma ve eksiltme yapmayı gerektiren becerilerde olumlu yönde farklılaşma gösterdikleri saptanmıştır. Bu durum okul öncesi eğitime sahip çocukların bilişsel gelişim açısından daha hazır ve şanslı olduğunu göstermektedir. Yine bu öğrencilerin, sonraki eğitim kademesinde özellikle akademik başarı açısından daha üst seviyelerde olması beklenmektedir. Araştırma bulguları mevcut araştırma sonuçlarını da destekler niteliktedir. 
Öz bakım becerileri ile ilgili araştırmaları incelediğimiz noktada, Çetinkaya (2012) tarafından gerçekleştirilen araştırmada 60-72 ay döneminde okula başlayan ve 36-48 ay döneminde okula başlayan çocukların öz bakım becerilerinin gerçekleşme durumları aile görüşleri açısından incelenmiştir. Çalışmanın sonucunda 36-48 ay döneminde okula başlayan öğrencilerin öz bakım beceri düzeylerinin okula $60-72$ ay döneminde başlayan öğrencilerin öz bakım becerileri düzeylerinden daha gelişmiş olduğu ortaya çıkmıştır. Başka bir araştırmada, Tamkavas (2003) cinsiyet ve okul öncesi eğitimi alma değişkenlerinin $60-72$ ay döneminde olan çocuklar açısından öz bakım becerilerini etkilemesi konusu incelenmiştir. Çalışmada okul öncesi eğitimin bu becerilere olumlu etki yaptığını tespit etmiştir. Çocukların kişisel bakım, giyinme becerileri, sınıf temizliği gibi konularda başarılı oldukları görülmüştür.

Konuyla ilgili bir başka araştırma ise Polat (2018) tarafından yapılan, öz bakım becerilerinin öğretmen adaylarının kullandığı günlük planlarında yer verilme durumu incelenmiştir. Çalışmanın neticesinde odak grup görüşmesinde yer alan öğretmenlerin öz bakım becerilerinin kazandırılması noktasında bu durumun önemli olduğunu düşündükleri ve bu konuda yardıma ihtiyaç duydukları kanısına ulaşılmıştır. Araştırma bulguları mevcut araştırma sonuçlarını da destekler niteliktedir.

Araştırmada okul öncesi eğitim programındaki öz bakım becerileriyle ilgili kazanımların gerçekleşme düzeyleri, öğretmen görüşleri doğrultusunda incelenmiştir. Bu kazanımları eğitim sürecinde etkinliklerle öğrencilere kazandıran yine öğretmenlerdir. Öğretmenlere ve araştırmacılara yönelik öneriler şu şekilde sıralanmaktadır:

- Öğretmenlerin öz bakım becerileri ile alakalı en az gerçekleştiğini düşündükleri kazanımlar "kendini tehlikelerden ve kazalardan korur ve sağllğı ile ilgili önlemleri alır" sonucu ortaya çıkmıştır. Öğretmenler çocukların otokontrol kazanmaları, öz disiplin ile tanışmaları ve herhangi bir durum karşısında problem çözme becerilerini geliştirebilmeleri açısından günlük programlarına bu alanları destekleyici etkinlikler almalıdır.

- Araştırmada katılımcı öğretmenlerin 60 ay ve üzerindeki çocukların kazanımları gerçekleştirme düzeyleri, 48-60 ay ve 36-48 ay yaş grubuna dâhil çocuklara oranla daha yüksektir görüşüne sahip oldukları görülmüştür. Buradan yola çıkarak eğitim programı içerisinde kazanım ve göstergelerin yaş grubu değişkeni göz önünde bulunarak gruplara ayrılmasının getirileri üzerine başka çalışmalar yapılabilir. Okul öncesi öğretmenleri ve veliler ile yapılan bu çalışma okul öncesi öğretmen adayları ile yapılabilir ve sonuçlar karşılaştırılabilir. Okul öncesi eğitim programında yer alan diğer alan kazanımları da gerçekleşme düzeyleri açısından incelenebilir.

\section{Kaynakça}

Atay, M. (2005). Çocukluk döneminde gelişim. Kök.

Can, A. (2019). Spss ile bilimsel araştırma sürecinde nicel veri analizi. Pegem Akademi.

Çetinkaya, A. (2002). Okul öncesi eğitime 5-6 yaşlarında başlayan öğrenciler ile 3-4 yaşlarında başlayan öğrencilerin öz bakım becerilerinin veli görüşlerine göre incelenmesi. Uşak Üniversitesi, Sosyal Bilimler Enstitüsü, Uşak.

Ekinci, O. (2011). Okul öncesi eğitimin ilköğretim birinci sınıföğrencilerinin başarısı üzerine etkisi. (Gaziantep ili örneği). (Yayımlanmamış Yüksek Lisans Tezi). Gaziantep Üniversitesi Sosyal Bilimler Enstitüsü, Gaziantep.

İş, A. (2017). Okul öncesi ve sinıf öğretmenlerinin 2013 okul öncesi eğitim programındaki kazanımların gerçekleşme düzeyine yönelik algıları. (Yüksek Lisans Tezi). Fırat Üniversitesi Eğitim Bilimleri Enstitüsü, Elazığ. 
Karasar, N. (2002). Bilimsel araştırma yöntemi. Nobel Yayınları.

Kay, M. A. (2015). 2013 Okulöncesi eğitim programındaki kazanımların uygulamadaki etkililiğine ilişkin öğretmen görüşlerinin incelenmesi. (Batman ili örneği). (Yayımlanmamış Yüksek Lisans Tezi). Firat Üniversitesi Eğitim Bilimleri Enstitüsü, Elazı̆̆.

Köksal, O., Doğal, A. ve Duman, A. (2016). Okul öncesi öğretmenlerinin okul öncesi eğitim programı hakkındaki görüşlerinin belirlenmesi. International Journal of Science, 46, 379-394.

MEB, (2013). Okul öncesi eğitim programı. T.C. Milli Eğitim Bakanlığı, Temel Eğitim Genel Müdürlüğü, Ankara.

Özkesmen, A. (2008). Okul öncesi eğitim alan ve almayan 1. sınıf öğrencilerinin akademik başarılarının yeni müfredat programa göre değerlendirilmesi. (Yayımlanmamış Yüksek Lisans Tezi). Kafkas Üniversitesi Sosyal Bilimler Enstitüsü, Kars.

Özsırkıntı, D., Akay, C. ve Bolat, E. (2014). Okul öncesi öğretmenlerinin okul öncesi eğitim programı hakkındaki görüşleri. (Adana ili örneği). Ahi Evran Üniversitesi Kırşehir Ĕ̆itim Fakültesi Dergisi, 15(1), 313-331.

Polat, D. (2018). Okul öncesi öğretmen adaylarının günlük planlarında öz bakım becerilerine yer verme durumlarının incelenmesi. (Yüksek Lisans Tezi). Bolu İzzet Baysal Üniversitesi Eğitim Bilimleri Enstitüsü, Bolu.

Tamkavas, E. (2003). 5-6 Yaş çocuklarının öz bakım becerilerinin cinsiyet ve okul öncesi eăitim alma durumuna göre incelenmesi. (Yayımlanmamış Yüksek Lisans Tezi). Selçuk Üniversitesi Sosyal Bilimler Enstitüsü, Konya.

Unutkan, Ö. P. A. (2007). Okul öncesi dönem çocuklarının matematik becerileri açısından ilköğretime hazır bulunuşluğunun incelenmesi. Hacettepe Üniversitesi Ĕ̆itim Fakültesi Dergisi, 32, 243-254.

Uzun H. (2007). Malatya ilinde okulöncesi eğitim programının uygulanmasında öğretmen görüşlerinin değerlendirilmesi. (Anasınıfları üzerine bir çalışma). (Yayımlanmamış Yüksek Lisans Tezi). İnönü Üniversitesi Sosyal Bilimler Enstitüsü, Malatya. 